\title{
Effect of Insulin on Glucagon Secretion Mediated Via Glucose Metabolism of Pancreatic A Cells in Ducks
}

\author{
F. Laurent, R. Gross, M. Lakili, and P. Mialhe \\ Institut de Physiologie et Chimie Biologique, Strasbourg, France
}

Summary. A possible action of insulin via glucose metabolism on the pancreatic $A$ cell response to glucose, was studied in ducks. 2-Deoxyglucose, a nonmetabolizable analogue of glucose was used. In normal ducks, the hyperglycaemia induced by 2-deoxyglucose (IV: $0.5 \mathrm{~g} / \mathrm{kg}$ ) resulted in hyperglucagonaemia, while the same degree of hyperglycaemia, induced by glucose infusion (IV injection $25 \mathrm{mg} / \mathrm{kg}$, and infusion $5 \mathrm{mg} / \mathrm{kg} / \mathrm{min}$ ) immediately suppressed glucagon secretion. In diabetic ducks, two days after subtotal pancreatectomy, glucose responsiveness of the A cell was abolished, but could be restored by insulin treatment before (IM $0.2 \mathrm{U} / \mathrm{kg}$ insulin $+8 \mu \mathrm{g} / \mathrm{kg}$ glucagon every $6 \mathrm{~h}$ ) and during (IV $3.6 \mathrm{mU} / \mathrm{kg}+$ infusion $0.9 \mathrm{mU} / \mathrm{kg} / \mathrm{min}$ ) the glucose test (IV: $0.5 \mathrm{~g} / \mathrm{kg}$ ). The normal response of the A cell to glucose was not observed in diabetic insulintreated ducks after the administration of 2-deoxyglucose (IV: $0.5 \mathrm{~g} / \mathrm{kg}$ ). These data suggest an inhibitory effect of the metabolism of glucose on the release of glucagon. In addition, the action of insulin on the A cell may be mediated by its effect on glucose metabolism within the A cell.

Key words: Glucose, insulin, glucagon, glucose metabolism, A cell, 2-deoxyglucose, subtotal pancreatectomy, ducks.

The existence of an important role of insulin in the modulation of $A$ cell responsiveness to glucose is now generally $([3,4,12,19,26]$ and Karmann H., personal communication) but not always [28] admitted. In the duck, insulin has been shown to exert a double action on the A cell's sensitivity to glucose, the existence of a long and short term action of insulin having been demonstrated [12].
However, the mode of action of insulin on the $A$ cell is poorly understood. Impairment of glucose oxidation, and particularly of glycolysis, has a stimulatory effect on glucagon secretion [5], while glucose suppresses A cell secretion [24]. The hypothesis that insulin causes suppression of glucagon secretion during hyperglycaemia by facilitating the metabolism of glucose within the $A$ cell has been raised in this context.

This question has been studied in the duck; a species in which glucagon assumes a particular importance $[20,21]$, and where transient diabetes can be induced by subtotal pancreatectomy $[12,20]$. In the present report, the effect of 2-deoxyglucose, a non metabolizable analogue of glucose [31], on the responsiveness of the $A$ cell to glucose in normal and diabetic ducks is examined.

\section{Material and Methods}

\section{1) Animals}

Adult male Peking ducks were used. The animals were taken indoors one day before the operation or test and kept in individual cages at room temperature, staying there between the surgery and the test. They were fed ad libitum on fowl pellets ("BPN Grands Moulins de Paris", Nancy, France) and tap water.

\section{2) Subrotal Pancreatectomy}

Surgery was performed under local anaesthesia with $1 \%$ lidocaine (Xylocaine, Bellon) according to Mialhe [20]. Only the round end of the splenic lobe of the pancreas was left.

\section{3) Treatment and Blood Sampling}

The ducks, fasted for 16 to $20 \mathrm{~h}$, were tied on their backs to a board throughout the experiment. They remained immobile under these conditions and no anaesthesia was needed. 
Blood samples were collected through a heparinized polyethylene catheter inserted into a wing vein, and kept on ice until centrifugation. Plasma was stored frozen until assayed.

A second catheter was connected to the infusion apparatus. Novo Actrapid pork insulin, Lilly pork glucagon, D- $(+)$-glucose (Merck), and 2-deoxy-D-glucose (Merck) were used in $0.154 \mathrm{~mol} / 1 \mathrm{NaCl}$ carrier solution.

\section{4) Protocols}

a) Glucose Tolerance Test in Normal Ducks. Glucose $(0.5 \mathrm{~g} / \mathrm{kg})$ was injected IV into normal fasted ducks. Blood samples were taken at $-10,0,2,5,10,20,30,45,60,90$ and $120 \mathrm{~min}$.

b) 2-deoxy-D-glucose (2-DG) Injections in Normal Ducks. 11 normal fasted ducks were injected IV with 2-DG at the rate of $0.5 \mathrm{~g}$ / $\mathrm{kg}$. The timing of the blood samples was the same as for glucose, 120 min being omitted.

c) Glucose Treatment in Normal Ducks. In order to reproduce the plasma glucose variations observed in 2-DG-injected ducks, 10 normal fasted animals were injected with $25 \mathrm{mg} / \mathrm{kg}$ glucose at $0 \mathrm{~min}$ and infused with glucose $(5 \mathrm{mg} / \mathrm{kg} / \mathrm{min})$ from 0 to $60 \mathrm{~min}$. The timing of the blood samples, in this case and in the following ones is the same als in protocol $b$.

d) Administration of Glucose and Insulin in Diabetic Ducks. Glucose $(0.5 \mathrm{~g} / \mathrm{kg})$ was injected IV into seven diabetic ducks, two days after subtotal pancreatectomy. They were treated with insulin $0.2 \mathrm{U} / \mathrm{kg}$ and glucagon $8 \mu \mathrm{g} / \mathrm{kg} \mathrm{IM}$ every six hours between the operation and the test. During the glucose test, they had an insulin injection at $0 \mathrm{~min}$ (IV, $3.6 \mathrm{mU} / \mathrm{kg}$ ), and an insulin infusion $(0.9 \mathrm{mU} / \mathrm{kg} / \mathrm{min})$ for one hour.

e) Administration of 2-DG + Insulin in Diabetic Ducks. Eight diabetic fasted ducks were submitted to the insulin treatment previously described. $2-D G(0.5 \mathrm{~g} / \mathrm{kg})$ was injected IV two days after subtotal pancreatectomy.

f) Administration of 2-DG in Diabetic Ducks. 2-DG was injected (IV, $0.5 \mathrm{~g} / \mathrm{kg}$ ) into seven diabetic ducks, two days after subtotal pancreatectomy.

g) Administration of Glucose in Diabetic Ducks. Glucose was injected $(1.75 \mathrm{~g} / \mathrm{kg}$, IV) into nine diabetic ducks, two days after subtotal pancreatectomy.

\section{5) Plasma Determinations}

Plasma glucose was measured with a Technicon autoanalyser by the method of Hoffmann [9].

Plasma immunoreactive insulin (IRI) was determined by radioimmunoassay, using a dextran coated charcoal method of separation [6] and Novo beef insulin as a standard. As reported previously [12], estimating mixtures of pork and duck insulin against a beef standard produces insignificant errors, at least at the physiological insulin levels reached here. The results are given as ng beef insulin equivalents/ml plasma.

Plasma total glucagon (GLI) was measured with the radioimmunoassay of Leclercq-Meyer et al. [15], using Novo pork glucagon as a standard, and expressed as ng porcine glucagon equivalents $/ \mathrm{ml}$ plasma. The antiserum " $7 / 69$ " used here is an $\mathrm{N}$-terminal specific antibody and is not specific for pancreatic glucagon. We are however able to assert that the plasma variations reported here correspond to real changes in pancreatic glucagon or $\operatorname{IRG}[12,13]$ since no GLI variations could be observed in totally pancreatectomized ducks injected with glucose [29]. In addition, the so-called "non specific antibodies", with affinity for the $\mathrm{N}$-terminal, are just those able to react fully with duck glucagon [8]. However some control determinations have been performed with a C-terminal specific antibody ( $30 \mathrm{~K}$, purchased from Dr. Unger's laboratory). The characteristics of the assay are given elsewhere [13].

\section{6) Statistical Method}

Student's "t" test was used. All mean values were compared to zero time and are given with the standard error of the mean (SEM).

\section{Results}

a) Glucose Tolerance Test in Normal Ducks (Fig. 1). Plasma glucose rose from $218 \mathrm{mg} / 100 \mathrm{ml}$ to an average of $462 \mathrm{mg} / 100 \mathrm{ml}$ two minutes after the injection. Plasma IRI immediately and significantly rose from 0.33 to an average of $0.53 \mathrm{ngEq} / \mathrm{ml}$ at $10 \mathrm{~min}$. Plasma GLI abruptly decreased from 1.28 to a nadir of $0.50 \mathrm{ngEq} / \mathrm{ml}$ at $5 \mathrm{~min}$ and the fall was statistically significant between 2 and $60 \mathrm{~min}$.

b) 2-deoxy-D-glucose (2-DG) Injection in Normal Ducks (Fig. 2). Plasma glucose was elevated from 2 to $90 \mathrm{~min}(\mathrm{p}<0.001)$. A significant change in plasma IRI occured from 5 to $20 \mathrm{~min}$. Plasma GLI, measured by $7 / 69$ antiserum, rose from 1.27 to $6.43 \mathrm{ngEq} / \mathrm{ml}$ at $2 \mathrm{~min}$. This increase corresponds to

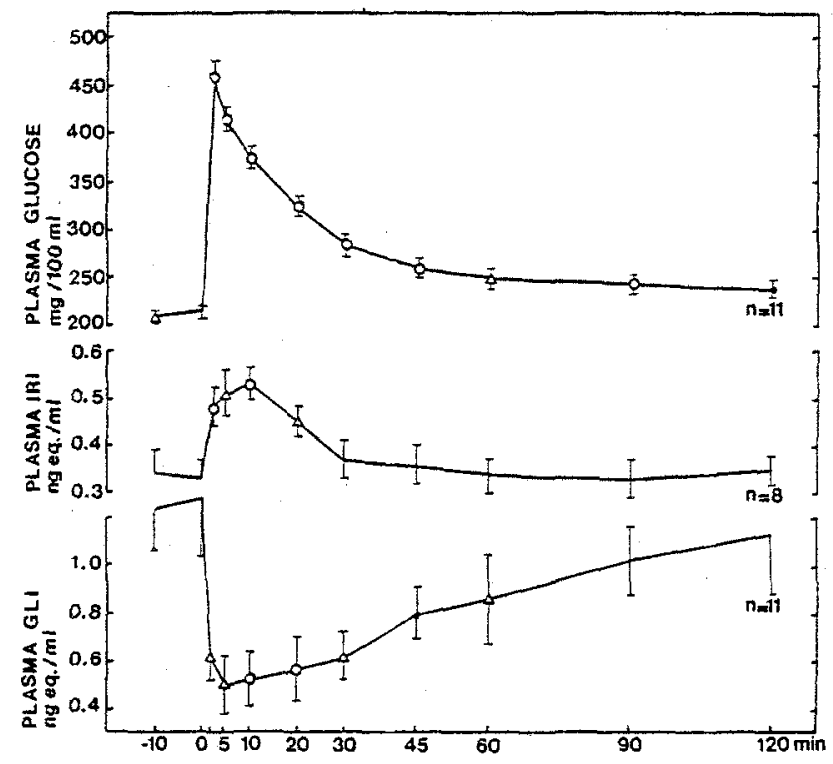

Fig. 1. Effect of a glucose IV injection $(0.5 \mathrm{~g} / \mathrm{kg})$ in normal fasted ducks, on plasma glucose, IRI and GLI. The number of determinations " $n$ " is given beside each curve. In this figure, as in the following ones, vertical bars represent $\pm S E M ; O, \triangle$ and $\bullet$ respectively correspond to $p<0.001, p<0.01$, and $p<0.05$ compared to zero time 


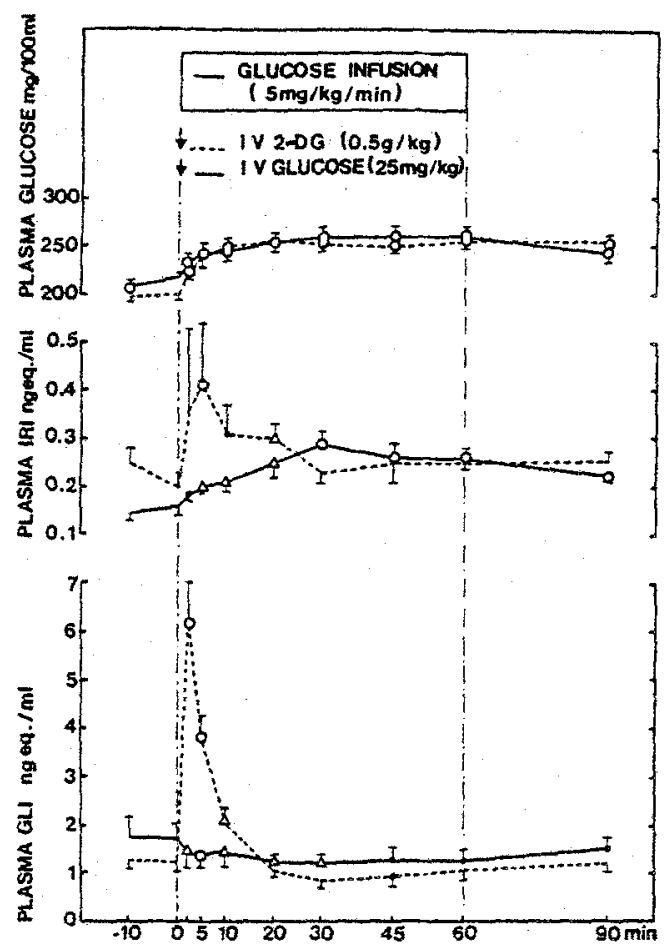

Fig. 2. Effect of a 2-DG IV injection $(0.5 \mathrm{~g} / \mathrm{kg})$ in 11 normal fasted ducks (- - ) and of a $25 \mathrm{mg} / \mathrm{kg}$ IV glucose injection, followed by an one hour glucose infusion $(5 \mathrm{mg} / \mathrm{kg} / \mathrm{min}$ ) in 10 normal fasted ducks (-), on plasma, glucose, IRI and GLI. Symbols as in Figure 1

pancreatic glucagon (IRG), as confirmed by $30 \mathrm{~K}$ antiserum (plasma glucagon rose from 1.06 to $6.06 \mathrm{ngEq} / \mathrm{ml}$ at $2 \mathrm{~min}(\mathrm{p}<0.05, \mathrm{n}=5)$.

c) Glucose Treatment in Normal Ducks (Fig. 2). Plasma glucose was elevated from 2 to $90 \mathrm{~min}$, and there was no significant difference from the glucose curve obtained after a 2-DG injection. A significant rise in plasma IRI occured as early as $2 \mathrm{~min}$, and was sustained throughout the whole experiment. In contrast with the preceding experiment, plasma GLI was significantly lower from 2 to $90 \mathrm{~min}$.

\section{d) Administration of Glucose and Insulin in Diabetic} Ducks (Fig. 3). In this study, there was no significant difference between basal plasma glucose and insulin levels before and two days after subtotal pancreatectomy. Plasma glucose rose immediately after the glucose injection and the hyperglycaemic curve was closely similar to that observed in normal ducks injected at the same glucose rate. Plasma IRI significantly rose from 0.22 to $0.67 \mathrm{ngEq} / \mathrm{ml}$ at $20 \mathrm{~min}$. Plasma GLI decreased from 1.39 to a nadir of $0.55 \mathrm{ngEq} / \mathrm{ml}$ at $5 \mathrm{~min}$, the fall being significant from

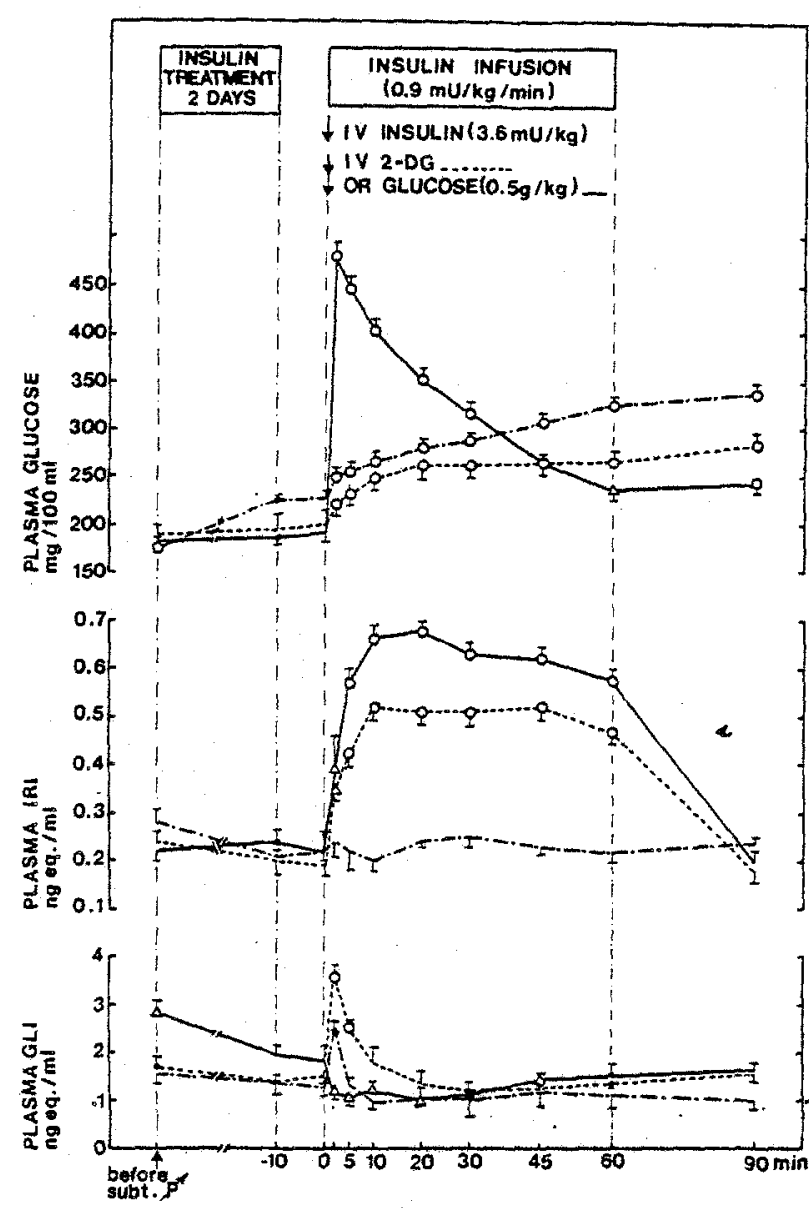

Fig. 3. Effect of an IV injection of $0.5 \mathrm{~g} / \mathrm{kg} 2-\mathrm{DG}(---, \mathrm{n}=8$ ) or $0.5 \mathrm{~g} / \mathrm{kg}$ glucose $(-, \mathrm{n}=7$ ) in transiently diabetic ducks treated with insulin before and during the test. Insulin $0.2 \mathrm{U} / \mathrm{kg}$ and glucagon $8 \mu \mathrm{g} / \mathrm{kg}$ were injected $\mathrm{MM}$ every $6 \mathrm{~h}$ between the operation and test, and a priming IV injection of $3.6 \mathrm{mU} / \mathrm{kg}$ insulin, followed by a one hour infusion of $0.9 \mathrm{mU} / \mathrm{kg} / \mathrm{min}$ insulin, was given during the test. This is compared with the effect of an IV injection of $0.5 \mathrm{~g} / \mathrm{kg} \mathrm{2-DG}$ in seven diabetic ducks, without any insulin treatment $(\cdot-\cdot-\cdot)$. Symbols as in Figure 1 ; subt. $\vec{P}^{\prime \prime}=$ subtotal pancreatectomy

2 to $60 \mathrm{~min}$. No significant difference was found when GLI changes in normal and diabetic insulintreated animals were compared. The area of glucagon decrement from 0 to $10 \mathrm{~min}$ was $6.90 \pm$ $1.53 \mathrm{ngEq} / \mathrm{ml} / 10 \mathrm{~min}$.

e) Administration of 2-DG+Insulin, in Diabetic Ducks (Fig. 3). Significant hyperglycaemia immediately developed after the 2-DG injection. Plasma IRI levels increased from 0.19 . to $0.52 \mathrm{ngEq} / \mathrm{ml}$ at $10 \mathrm{~min}$, and plasma GLI acutely rose $(p<0.001$ at 2 and $5 \mathrm{~min}$ ) after the 2-DG injection. The area of glucagon increment was $9.73 \pm 1.63 \mathrm{ngEq} / \mathrm{ml} /$ $10 \mathrm{~min}$ during the first $10 \mathrm{~min}$. 


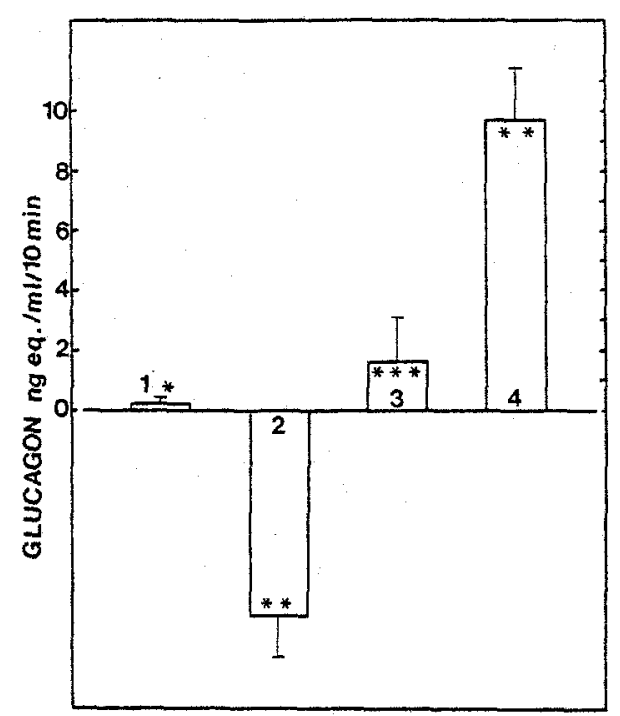

Fig. 4. Areas of glucagon increment or decrement during the first 10 min following the IV injection in diabetic ducks two days after subtotal pancreatectomy. 1: diabetic ducks, injected IV with glucose $(1.75 \mathrm{~g} / \mathrm{kg}) ; \mathrm{n}=9.2$ : diabetic insulin treated (see Fig. 3) ducks, injected IV with glucose $(0.5 \mathrm{~g} / \mathrm{kg}) ; n=7.3$ : diabetic ducks, injected IV with 2-DG $(0.5 \mathrm{~g} / \mathrm{kg}) ; \mathrm{n}=7.4$ : diabetic insulin treated (as Fig. 3) ducks injected IV with 2-DG $(0.5 \mathrm{~g} / \mathrm{kg}) ; \mathrm{n}=7$. * indicates a significant difference $(p<0.01)$ from other groups except group 3. ${ }^{* *}$ : a significant difference $(p<0.01)$ with all other groups. ***: a significant difference $(p<0.01)$ with other groups except with group 1

f) Administration of 2-DG in Diabetic Ducks (Fig. 3). Plasma glucose rose from 228 to $250 \mathrm{mg} / 100 \mathrm{ml}$ at 2 min. No significant change in plasma IRI or GLI could be observed, except a small rise in GLI at $2 \mathrm{~min}$, and the area of glucagon secretion variation from 0 to $10 \mathrm{~min}$ was $1.62 \pm 1.52 \mathrm{ngEq} / \mathrm{ml} / 10 \mathrm{~min}$.

g) Administration of Glucose in Diabetic Ducks. No significant change in plasma insulin and GLI occured after the glucose injection and the area of glucagon secretion variation $(0.18 \pm 0.56 \mathrm{ngEq} / \mathrm{ml} / 10 \mathrm{~min})$ was not significantly different when compared with diabetic animals given 2-DG (Fig. 4).

\section{Discussion}

The role of insulin in the $A$ cell responsiveness to glucose in ducks has been studied previously using as a diabetes model subtotally pancreatectomized ducks. The existence of a long-term and of a shortterm action of insulin on the A cell was demonstrated
[12]. The dependency of normal glucose metabolism within the A cells on a long term action of insulin is studied here, using 2-DG.

\section{1) Specific and Non-specific Effects of 2-DG}

In order to block glucose metabolism, we used 2-deoxyglucose (2-DG), a non metabolizable analogue of glucose. 2-DG appears to block glycolysis below the level of glucose-6-phosphate by competitive inhibition of the phosphohexoisomerase [31]. 2-DG seems to induce an adrenergic discharge affecting glucagon and insulin secretions in mammals [7]. In the duck, however, an adrenergic effect of 2-DG on B and A cells, if existing, can only be negligible. Indeed, in diabetic animals, the response of the $\mathrm{B}$ cell to hyperglycaemia is the same in the absence or the presence of 2-DG. Since an $\alpha$ adrenergic effect of 2-DG would have produced an inhibition, and a $\beta$ effect a stimulation of insulin secretion (Gross R.: personal communication), the absence of an adrenergic effect of 2-DG on the $B$ cell is suggested.

Since there is no significant difference between the areas measuring glucagon secretions during the first $10 \mathrm{~min}$ after glucose and 2-DG in untreated diabetic ducks (Fig. 4), the adrenergic effect of 2-DG can only be insignificant. However, the small increase in glucagon secretion at 2 min observed in untreated diabetic ducks given 2-DG might be attributed to a weak and brief adrenergic effect. The latter cannot account for the marked hyperglucagonaemia observed in treated diabetic ducks given 2-DG, since there is a significant difference $(p<0.01)$ between the areas of glucagon increment in treated and in untreated diabetic ducks given 2-DG (Fig. 4). So the hyperglucagonaemia observed in treated diabetic, as well as in normal ducks is mainly, if not entirely, due to a blockade of glucose metabolism, which is known to induce hyperglucagonaemia, even in vitro $[5,27]$.

\section{2) Glucose Metabolism and A Cell Responsiveness to Glucose}

A physiological hyperglycaemia induces an increased insulin response and suppresses glucagon secretion, as already shown in the duck with larger amounts of glucose [12], as well as in the goose [30] and in the dog [24], under physiological conditions.

The slight hyperglycaemia induced by $2-D G$ in normal animals is associated with marked hyperglucagonaemia and delayed hyperinsulinaemia, while suppression of glucagon secretion and an immediate increase in $B$ cell response occur in the absence of 2-DG. The slight inhibition of the B cell response to glucose observed in the presence of 2-DG might be 
explained by a transient blockade of glucose metabolism within the B cell. So glucose metabolism of the $B$ cell seems to be a prerequisite for insulin release in the duck, as in mammals $[2,14]$. In addition, blockade of glucose metabolism during hyperglycaemia induces hyperglucagonaemia. So intracellular glucose metabolism within the A cell may have an inhibitory effect on the secretion of glucagon in response to glucose, as already shown in vitro $[5,16]$ though there are arguments for a role of nucleotides in the response of the $A$ cell $[1,10]$. Both meçhanisms may be involved as in the $B$ cell [2].

\section{3) Action of Insulin on the Glucose Metabolism of the $A$ Cell}

In diabetic ducks, no response of $\mathrm{A}$ or $\mathrm{B}$ cells to glucose can be observed two days after subtotal pancreatectomy, even with supraphysiological amounts of glucose [12]. However, the above results (Fig. 3) indicate that when diabetic ducks are treated with insulin before and during a glucose test, in order to restore normal basal insulin levels and normal insulin variations during a physiological hyperglycaemia, an immediate decrease in glucagon secretion occurs, as already shown in the duck with supraphysiological glucose concentrations [12]. The existence of an action of insulin on the suppression of glucagon secretion by glucose is now demonstrated in the duck under physiological conditions.

Moreover, the blockade of glucose metabolism in these diabetic, insulin-treated animals induces a rise in glucagon secretion, in spite of the concomitant hyperglycaemia. It can thus be suggested that the suppressive effect of insulin on glucagon release could be mediated via stimulation of glucose metabolism within the A cell. A possible site of action of insulin might be in the glycolytic pathway, below the glucose-6-phosphate step. In agreement with this, Lundqvist [17] reported that the phosphorylation of glucose in the A cells is of lower regulatory importance than in the B cells.

The present observation, that normal glucose metabolism within the A cells is an insulin-requiring process, without which hyperglycaemic suppression of the glucagon release cannot occur, has already been suggested by in vivo experiments in the dog [23]. However, in vitro findings are conflicting. Experiments on guinea pigs [26] are in favour of a suppressive effect of insulin on glucagon release via stimulation of glucose metabolism of the A cell, while several other reports on the rat $[25,28]$ fail to confirm these results. The suppression of the aminogenic glucagon secretion by glucose seems to be insulinindependent. It is possible, however, that control of glucagon secretion below the basal secretory rate involves an insulin-dependent mechanism, while glucose control of the aminogenic response involves a separate insulin-independent function, at least in mammals, since in the duck, the aminogenic glucagon secretion seems to be both glucose and insulin independent [13].

In conclusion, intracellular glucose metabolism may be an essential step in the response of the pancreatic A cell to glucose. Moreover, insulin could modulate glucagon secretion in response to glucose via glucose metabolism in the A cell.

Acknowledgements. The authors wish to thank Miss Horrenberger, Mrs M. Roth and G. Sommermeyer for their heipful assistance, and Miss Elisabeth Gauvin for typing the manuscript.

Pork glucagon was a gift from Novo Industrie and E. Lilly, pork and beef insulin from Novo Industrie and Boots.

This study was supported by the CNRS (ERA 188), the INSERM (contrat $n^{\circ} 75.1 .051 .4$ ), and the FRMF.

\section{References}

1. Andersson A, Groth $C G$, Gunnarsson $R$, Hellerström $C$, Lundgren G, Petersson B, Ostman J (1978) Metabolic and secretory characteristics of cultured buman islets of Langerhans. In: Esmann V (ed) Regulatory mechanisms of carbohydrate metabolism. FEBS, $11^{\text {th }}$ Meeting, Copenhagen 1977, vol 42. Pergamon Press, Oxford New York, p 249-257

2. Aschcroft SJH (1980) Glucoreceptor mechanisms and the control of insulin release and biosynthesis. Diabetologia 18: $5-15$

3. Aydin I, Raskin P, Unger RH (1977) The effect of short-term intravenous insulin administration on the glucagon response to a carbohydrate meal in aduit onset and juvenile type diabetes. Diabetologia 13: 629-636

4. Braaten JT, Faloona GR, Unger RH (1974) The effect of insulin on the alpha cell response to hyperglycaemia in longstanding alloxan diabetes. J Clin Invest 53: 1017-1022

5. Edwards JC, Taylor KW (1970) Fatty acids and the release of glucagon from isolated guinea-pig islets of Langerhans incubated in vitro. Biochim Biophys Acta 215: 310-315

6. Foltzer C, Mialhe P (1976) Pituitary and adrenal control of pancreatic endocrine function in the duck. II Plasma free fatty acids, aminoacids, and insulin variations following hypophysectomy and replacement therapy with growth hormone and corticosterone. Diabete Métab 2: 101-105

7. Frohman LA, Nagai K (1976) Central nervous system-mediated stimulation of glucagon secretion in the dog following 2-deoxyglucose. Metabolism [Suppl] 1: 1449-1952

8. Heding LG, Frandsen EK, Jacobsen H (1976) Structure-function relationship: immunologic. Metabolism [Suppl] 1: $1327-1329$

9. Hoffmann WS (1937) A rapid photoelectric method for the determination of glucose in blood and urine. J Biol Chem 120: $51-55$

10. Jarrousse C, Rosselin G (1975) Interaction of aminoacids and cyclic AMP on the release of insulin and glucagon by newborn rat pancreas. Endocrinology 96: 168-177

11. Jean Marie P (1972) Effet de la pancréatectomie et de l'hypophysectomie sur la circulation des lipides chez le canard. Thesis, Université Paul Sabatier, Toulouse 
12. Laurent $F$, Mialhe $P(1976)$ Insulin and the glucose-glucagon feedback mechanism in the duck. Diabetologia 12: 23-33

13. Laurent $F$, Mialhe $P$ (1978) Effect of free fatty acids and aminoacids on glucagon and insulin secretion in normal and diabetic ducks. Diabetologia 15: 313-321

14. Larson BA, Williams TL, Showers MO, Wanderlaan WP (1979) Effect of 2-deoxyglucose on $\left[{ }^{32} \mathrm{p}\right]$ Phosphate and insulin release from perifused rat pancreatic islets. Diabetologia 17: $117-120$

15. Leclercq-Meyer V, Mialhe P, Malaisse WJ (1970) Une méthode de dosage radioimmunologique du glucagon comportant une séparation par le charbon dextran. Diabetologia 6: 121-129

16. Leclercq-Meyer V, Marchand J, Leclercq R, Malaisse WJ (1979) Interaction of $\alpha$ ketoisocaproate, glucose and arginine in the secretion of glucagon and insulin from the perfused rat pancreas. Diabetologia 17: 121-126

17. Lundqvist C (1972) Enzymatic studies of glucose phosphorylation in the glucagon producing cell of the duck pancreas. Horm Metab Res 4: 83-86

18. Marliss EB, Aoki TT, Cahill GF (1972) Glucagon and aminoacid metabolism. In: Lefebvre PJ, Unger RH (ed) Glucagon. Molecular physiology, clinical and therapeutic implications. Pergamon Press, Oxford, p 123-150

19. Massi-Benedetti F, Falorni A, Luyckx A, Lefebvre P (1974) Inhibition of glucagon secretion in the human newborn by simultaneous administration of glucose and insulin. Horm Metab Res 6: 392-396

20. Mialhe $P$ (1958) Glucagon, insuline et régulation endocrine de la glycémie chez le canard (Thesis): Acta Endocrinol [Suppl] (Kbh) 36: 1-134

21. Mialhe $P$ (1976) The role of glucagon in birds and mammals. In: Grillo TAI, Liebson L, Epple A (eds) The evolution of pancreatic islets. Pergamon Press, Oxford, p 291-300.

22. Mialhe P, Krug E, Gross R (1976) Hormonal control of lipolysis: comparative aspects. In: James VHT (ed) Proceedings of the $\mathrm{V}$ International Congress of Endocrinology, Hamburg. Endocrinology, vol 2, ICS 403. Excerpta Medica, Amsterdam, p 548-553

23. Müller WA, Faloona GR, Unger RH (1971) The effect of experimental insulin deficiency on glucagon secretion. $\mathrm{J}$ Clin Invest 50; 1992-1999

24. Ohneda A, Aguilar-Parada E, Eisentraut AM, Unger RH
(1969) Control of pancreatic secretion by glucose. Diabetes 18: $1-10$

25. Oliver JR, William VL, Wright PH (1976) Studies on glucagon secretion using isolated islets of Langerhans of the rat. Diabetologia 12: 301-306

26. Óstenson CG, Andersson A, Brolin SE, Petersson B, Hellerström C (1977) Effects of insulin on the glucagon release, glucose utilization and ATP content of the pancreatic A cell of the guinea pig. In: Foa PP, Bajaj JS, Foa NL (eds) Glucagon: its role in physiology and clinical medecine. Springer, Berlin Heidelberg New York, p 243-254

27. Óstenson CG, Agren A, Andersson A (1979) Effect of metabolic inhibitors on the regulation of pancreatic glucagon release. In: Regulation of glucagon biosynthesis and secretion in isolated mammalian pancreatic islets. Thesis, Acta Universitatis Uppsaliensis, Uppsala

28, Pagliara AS, Stillings SN, Haymond MW, Hover BA, Matschinsky FM (1975) Insulin and glucose as modulators of the aminoacid-induced glucagon release in the isolated pancreas of alloxan and streptozotocin diabetic rats. $\mathrm{J}$ Clin Invest 55: 244-255

29. Samols EJ, Tyler JM, Marks V, Mialhe P (1968) The physiological role of glucagon in different species. In: Gual $G$ (ed) Proceedings of the III International Congress of Endocrinology, Mexico. Progress in Endocrinology, ICS 184. Excerpta Medica, Amsterdam, p 206-219

30. Sitbon G, Mialhe P (1978) Pancreatic hormones and plasma glucose regulation mechanisms in the goose under physiological conditions II Glucose-glucagon and glucose-insulin feedback mechanisms. Horm Metab Res 10: 117-123

31. Wick AN, Drury DR, Nakada HI, Wolfe JB (1957) Localization of the primary metabolic block produced by 2 -deoxyglucose. J Biol Chem 224: 963-969

Received: May 2, 1979,

and in revised form: September 30, 1980

\section{Dr. F. Laurent}

Institut de Physiologie Générale

21 rue René Descartes

F-67084 Strasbourg

France 